\title{
Resisting legitimacy: Weber, Derrida, and the fallibility of sovereign power
}

\section{Thomas Clément Mercier}

To cite this article: Thomas Clément Mercier (2016) Resisting legitimacy: Weber, Derrida, and the fallibility of sovereign power, Global Discourse, 6:3, 374-391, DOI: 10.1080/23269995.2016.1151729

To link to this article: https://doi.org/10.1080/23269995.2016.1151729
(2) 2016 The Author(s). Published by Informa UK Limited, trading as Taylor \& Francis Group.

册 Published online: 09 Mar 2016.

Submit your article to this journal

\section{Article views: 3859}

\section{Q View related articles $\asymp$}

View Crossmark data $\nearrow$

4 Citing articles: 3 View citing articles 


\section{Resisting legitimacy: Weber, Derrida, and the fallibility of sovereign power}

\section{Thomas Clément Mercier}

Department of War Studies, King's College, London, UK

\begin{abstract}
In this article, I engage with Derrida's deconstructive reading of theories of performativity in order to analyse Max Weber's sovereignty-legitimacy paradigm. First, I highlight an essential articulation between legitimacy and sovereign ipseity (understood, beyond the sole example of State sovereignty, as the autopositioned power-to-be-oneself). Second, I identify a more originary force of legitimation, which remains foreign to the order of performative ipseity because it is the condition for both its position and its deconstruction. This suggests an essential fallibility of the performative, which implies a 'mystical' legitimacy and a paradoxical, divisible and self-differential representation of sovereignty. The structural differentiality of legitimacy and sovereignty signifies an irreducible coloniality of law and language, but also suggests the possibility of an unconditional resistance located in the radical interpretability of the law, beyond determined representations of powers, dominations, sovereignties or resistances. This reflection is triggered by a reading of Cynthia Weber's theory of 'performative states', describing sovereignty under the form of an impossible ontology, which leads me to elaborate the notion of legitimation-to-come as a non-ontological 'concept': this notion of unconditional legitimacy, beyond sovereignty, binds beliefs and phantasms to the unpresentable force of the event. Pursuing the efforts of scholars such as Rob Walker and Cynthia Weber, I sketch the implications of this archi-performative legitimacy regarding the methodological protocols of International Relations and sociology, in view of elucidating the persistent ontological presuppositions of these disciplines.
\end{abstract}

\section{KEYWORDS}

Legitimacy; sovereignty; performativity; deconstruction; Jacques Derrida; Max Weber; State theory; International Relations theory

[S]overeignties are rarely as structurally, logically or topologically tight as their practices would have us believe. Sovereignties fall apart in the always potential contingency of everyday life. Even the most absolute sovereign authority has unintended consequences. What can go wrong often does. The unanticipated happens.

(Walker 2010, 192)

Until recently, sovereignty was conceived as infallible. Etymologically, the name suggests a hyperbolic superiority, superiority itself ${ }^{1}$; it implies the automatic success of a self- 
legitimating, autonomous arkhe, instantiating power as commencement, originary authority and principle of command. Through the defining feature of selfdetermination, sovereignty supposedly excludes failure. This exclusion permeates all its philosophical and sociological definitions, even the most empirical or critical. Failure was certainly not an option for the triumphant State such as defined by Max Weber - to the extent that the term 'success' (Erfolg) was made part of its definition:

The state is the human community that, within a defined territory - and the key word here is 'territory' - (successfully [mit Erfolg]) claims the monopoly of legitimate force for itself. $(2008,156,2012,397)^{2}$

It is impossible to overestimate the importance of this definition for subsequent works in sociology and international relations (IR). One could argue that the whole history of IR consisted in unfolding the theoretical implications of Weber's definition for the international, followed by its meticulous deconstruction in the hands of constructivists and poststructuralists. Schematically, the main objects of contention were: Weber's postulate that the State's monopoly of legitimate violence could be contrasted with international anarchy, and its influence on Morgenthau, Aron and subsequent 'Realism' (Ashley 1988; Walker 1993a, 1993b, 180; C. Weber 2010, 20-21); Weber's inscription of the State within a definite territory, thus essentialising structural categories of inside/outside (Walker 1993b, 126), and defining them according to sovereign 'ontopology' (Derrida 1994, 102; Campbell 1998, 80); Weber's reluctance to account for the State's foreign policy and its decisive role in defining the State's prerogatives as a systemic actor (Thomson 1994; C. Weber 1995, 106); the incapacity of the definition to encompass all forms of sovereign States (C. Weber and Biersteker 1996, 14), and its overall lack of historicity (Thomson 1994).

These studies have profoundly reshaped IR theory by challenging one of its most persistent presuppositions. Here, I offer a theoretical examination of Weber's definition by emphasising two terms, 'success' and 'present', which durably influenced our views of the State as a nexus of sovereignty and legitimacy, and our conception of political theory as an ontology of domination. The second term, 'present', immediately follows Weber's definition: his description reflects 'the specific characteristic of the present (Gegenwart)' $(2008,156)$. This appeal to contemporaneity, to the presence of the present, is constant in Weber's 'sociology of domination', explicitly positing the State as a finished product, achievement and telos: 'the concept of the state has only in modern times reached its full development' $(1978,56)$. The motifs of 'success' and 'presence' consolidate each other and orientate the whole of Weber's theory of politics as domination (Herrschaft) through its culmination in the State. But what are the presuppositions in defining legitimacy ontologically, from the perspective of present success?

In this article, I interrogate Weber's socio-ontology of success, by challenging the coconstitutionality of sovereignty and legitimacy and by emphasising their structural fallibility. First, I analyse Cynthia Weber's seminal critique of IR theory and her interpretation of State sovereignty as performative. Performativity theories de-naturalise legitimacy by exposing its discursive character: the State performs itself by successfully producing the conditions of its legitimacy and legibility. I extend this analysis, beyond the example of State domination, to the accreditation of 'ipseity', that is, the definition of the self-same, or self-presence. According to Jacques Derrida: 
Before any sovereignty of the state, of the nation-state, of the monarch, or, in democracy, of the people, ipseity names a principle of legitimate sovereignty, the accredited or recognized supremacy of a power or a force, a kratos or a cracy. $(2005 a, 12)$

Performative interpretations of legitimacy run the risk to validate this recognition of ipseity, and to enact an ontology of political domination tacitly acknowledging State sovereignty as successful autoposition: what Derrida names 'ipsocentrism', or 'ipsocracy' (2005a, 17, 51). By contrast, I highlight, following Derrida, a principle of fallibility consubstantial with performativity. This leads me to emphasise the differential and phantasmatic structure of legitimacy, and to elaborate the non-ontological and postperformative notion of 'legitimacy-to-come'. It suggests an unconditional resistance beyond ipseity, exceeding discourses of successful self-presence and performative legitimacies.

\section{Performativity, sovereignty and legitimacy}

J.L. Austin inaugurated performativity studies by attempting to distinguish between performative and constative dimensions of language. He suggested that constatives are either true or false, while performatives instantiate their own event, and thus cannot be said to be true or false within admitted conditions of referentiality $(1962,4,25)$. One of the most powerful gestures of critical IR was to de-naturalise State sovereignty by emphasising its performative dimension. This resulted in reframing IR theory. The notion of performativity questions the methodological foundations and the conceptual protocols of the discipline, notably by challenging the limit between theory and praxis. In her essay 'Performative States' (1998), Cynthia Weber argues that 'sovereign nation-states are not pre-given subjects but subjects in process and that all subjects in process (be they individual or collective) are the ontological effects of practices which are performatively enacted' $(1998,78)$. Drawing on the work of Judith Butler, she suggests that States are constructed discursively in ways that posit the State and its four components authority, territory, population and recognition - as 'natural' and 'prediscursive' $(1998,92)$.

While performativity studies have always been concerned with questions of legitimation, these never quite came to the centre of the argument. ${ }^{3}$ This might be due to a structural difficulty regarding the 'juridical power' of the performative (Butler 1997, 48), on which the articulation between performativity and legitimacy relies. Indeed, the performative finds itself on both 'sides' of the legitimation process: it must always be legitimated (this is the condition of its 'success' or 'felicity') and legitimating (because it produces an utterance with juridical value). Performativity is a principle of foundation and conservation (Derrida 2002b, 272-277), thus blurring the limit between foundational and procedural representations of legitimacy. This double-sidedness seems to imply a tautological circularity which disseminates the origin of legitimacy. The question of legitimation concerns: (1) the performative statement under scrutiny - for instance, such or such practice or discourse of State sovereignty; (2) the legitimacy of the performative conventions which have supposedly legitimated or enabled said practice or discourse; (3) the legitimacy of the interpretative models through which one appraises these matters of performativity-legitimacy. Each one of these analytical levels 
may, at once or in turn, be envisaged as performative or constative, as legitimating or legitimated device, which allows for all possible confusions, conflations, with the risk to validate, qua performative ontologisation or essentialisation, existing structures of legitimation. In isolating a performative in view of theoretical or critical appraisal, one must always presuppose (at least provisionally) the presence and legitimacy of contextual conventions that made the performative 'successful' or 'unsuccessful', and made the critical pondering of this 'success' possible in the first place. This interpretative effort involves a performative selection that cannot be entirely neutral, or can only pretend to be so by masquerading itself into a theoretical constative.

This problematisation of performative legitimacy directly concerns sovereignty, inasmuch as sovereign power presents itself as the unchallenged foundation of legitimacy and law. However, like performatives, singular sovereign decisions (characterised, at least in principle, as self-determined and autoposited) may be placed, depending on interpretations or appraisals, on either side of the legitimating-legitimated divide. In all rigour, the logic of performative sovereignty requires that performatives enclose themselves into a perfect, tautological circle of self-justified force and forceful self-justification. The notion of 'successful' performative would thus allow the closure of this circle in the fictional moment of its inauguration. In this moment, the performative is force, is legitimacy, is selfhood, is performative, etc. - 'performative tautology or a priori synthesis' (Derrida 2002b, 267). This tautological position suggests an absolute self-referentiality, the sui generis capacitating title of a performative power which would ultimately rely only on itself to produce the discourse of its self-legitimation, thus consolidating the phantasm of an ipsocratic coup de force:

A 'successful' revolution, the 'successful' foundation of a state (in somewhat the same sense that one speaks of a 'felicitous performative speech act') will produce after the fact [après coup] what it was destined in advance to produce, namely, proper interpretative models to read in return, to give sense, necessity and above all legitimacy to the violence that has produced, among others, the interpretative model in question, that is, the discourse of its self-legitimation. (Derrida 2002b, 270)

The term 'success' thus carries the weight of the argument. The epistemic risk is to validate the phantasm of sovereign ipseity by confirming and closing this 'hermeneutic circle' through the authority of another performative (Derrida 2002b, 270). In accrediting this ontological circularity, one enacts, seemingly constatively, but always through some performative interpretation (with practical implications), the 'success' of the sovereign performative and of its self-legitimation. Sovereignties thrive on this a priori conflation of performative and constative, because it results in equating sovereignty with its 'own' performative power, as if it were indeed the product of its 'own' narrative.

If I emphasise the self-legitimating dimension of the performative, it is because selflegitimation or 'self-justification' (Selbstrechtfertigung) plays a decisive role in Max Weber's sociology of domination. Indeed, Weber defines politics and the State as structures of domination (Herrschaftstrukturen) inasmuch as they acquire and sustain legitimacy: 'the continued exercise of every domination (in our technical sense of the word) always has the strongest need of self-justification through appealing to the principles of its legitimation' $(1978,954)$. According to Weber, the need for legitimacy is a 'universal fact' concerning all displays of power or force (Macht). Legitimacy modifies 
power into domination (Herrschaft) by affecting its 'empirical structures' (1978, 953, $1980,549)$. In this presentation, legitimation operates according to a logic of supplementarity (Derrida 1997, 163): self-legitimation contributes to power structures at an essential level by constructing the 'legend' of superiority, but is defined as a nonoriginary characteristic of the order since it only justifies already-existing 'superiorities' (Weber 1978, 953-954; 1980, 549-550). Power, as dominant power, superior mastery, superiority itself, is postulated as already-existing subject, a powerful ipseity which generates its own 'legend', the discourse of its self-legitimation. Power comes first, as the factual superiority of a 'real' ipseity (the dominant subject: an individual, or a group of individuals), which merely needs to justify this powerful position, and does so because it can. It has the power to do so because it has the power to be itself and thus to justify itself. Power is its own origin, self-present, a 'prediscursive' selfness (as Cynthia Weber puts it), a site from which it can generate legitimacy as mere supplement.

\section{Fallible performatives}

Despite critical potentialities enabled by performativity theories, the risk is to essentialise sovereignty and legitimacy and to give credit to the performative gesture by conceiving it as successful - even when the intent is to criticise it.

However, Butler explained in Excitable Speech, ${ }^{4}$ following Derrida, that 'the failure of the performative is the condition of its possibility': 'That performative utterances can go wrong, be misapplied or misinterpreted, is essential to their "proper" functioning' (1997, 151). This fallibility of the performative is necessary for a simple reason: if the performative were absolutely conform to pre-existing referents or norms, if it merely validated or enacted, without rupture or 'distance', the legitimating conventions which supposedly enabled it, then it could not be said to produce an event in any meaningful way (while this is the condition for performativity [Austin 1962, 56]). This performative would not even be identifiable as such: it would escape all possibility of representation, interpretation or appraisal. If it is to produce an event, a performative must involve a rupture of context, some interpretative gesture vis-à-vis existing norms, thus exposing itself, from the onset, to counter-interpretations: the conditions of its legitimacy are the conditions of its illegitimacy, because the performative can never thoroughly stabilise all protocols of legitimation as it opens itself to other interpretations, other protocols of legitimacies, legitimacies-to-come.

As such, the performative must always fail to be unmitigatedly legitimate and legitimated; the conditions of its 'success' or 'failure', the very conditions of its theoretical or empirical intelligibility, depend on future interpretations. These can never, for the same reasons, present themselves absolutely and without contradiction. Legitimating discourses aim to suture the contradictions inherent to the performative by fabricating a cohesive narrative; however, the self-differential character of such discourses cannot be absolutely contained, and is bound to surge under the form of an event, contradicting and altering self-legitimating narratives. The event is a 'force of rupture', otherly, excessively unpredictable because it disrupts the powers of anticipation consubstantial with performative ipseity (Derrida 1994, 37). Legitimacy can only stabilise, forcefully but imperfectly, the force of the event (Derrida 2002a, 235); its function is to provisionally repress the event, that is, its constitutive otherness. However, otherness precedes and 
challenges the position of self-legitimating narratives; as such, it is an immanent force of alteration. This force of différance affects the performative before and beyond its stabilisation into determined performative 'acts', 'subjectivities', 'powers', 'authorities' or 'dominations' - all of which we may call, following Cynthia Weber, 'performative states' (be they 'states' or 'States').

Since it depends on future interpretations, reconstructions and legitimations, the true 'success' of the performative remains to come: it does not present itself ontologically, and remains ultimately enclosed into a mystique. I emphasise this notion because the 'mystical' will return in my analysis of Max Weber's verstehende Soziologie:

Even if the success of performatives that found a law (for example, and this is more than an example, of a state as guarantor of a law) presupposes earlier conditions and conventions (for example, in the national and international arena), the same 'mystical' limit will reemerge at the supposed origin of said conditions, rules or conventions, and at the origin of their dominant interpretation. (Derrida 2002b, 242)

Essentially secretive, self-differential, performatives involve an obligating force of law which remains irreducibly anchored in some fabulous of fictional power. Performative 'success' cannot present itself as such; it ultimately relies on belief, and this is what the concept of legitimacy comes to express: 'The performance of legitimacy is the credible production of the legitimate, the one that apparently closes the gap which makes it possible' (Butler 1997, 151). The performative thus capitalises on 'credibility' (to use Butler's term), on 'beliefs' (to use Max Weber's term), or on what Derrida calls, thus naming the paradoxical effectiveness of this 'make-believe' without opposite, the phantasma:

phantasma also named for the Greeks the apparition of the specter, the vision of the phantom, or the phenomenon of the revenant. [...] No more than myth, fable and phantasm are doubtless not truths or true statements as such, but neither are they errors or deceptions, false witness or perjuries. $(2002 a, 28)$

The notion of phantasmatic legitimacy would thus imply a hauntological (rather than ontological) understanding of performativity (Derrida 1994, 202). Etymologically, 'performativity' suggests an act which can fully accomplish the event that it instantiates: 'to perform' derives from Old French parfornir (to carry out, furnish completely). Such conception of performativity entails full self-presence. In contrast, phantasmaticity would signify an unfulfilled performance, incapacitated in its effort to instantiate the event that it strives to perform. By definition, a phantasm does not present itself: it exceeds categories of felicity or infelicity, veraciousness or falsity, being and nothingness. Phantasmaticity suggests a non-ontological relation to truth and legitimacy: it is neither representational (like the constative) nor (self-)presentational (like the traditional performative).

\section{Deconstructing the sovereignty-legitimacy paradigm: coloniality and symbolic powers}

Accounting for the fallibility of legitimation challenges Max Weber's co-implication between sovereign power and legitimacy. In several places in Economy and Society, Weber thematises legitimation as an instrumentalisation of 'cultural phenomena' in order to consolidate domination. Weber's conception of domination presupposes a spontaneous obedience, 
some irreducible 'will to obey' $(1980,122)$, which may be politically fostered through influencing cultural or psychological factors allowing obedience. This includes forms of 'mass domestication' through the efforts of religious authorities $(1978,477)$, the production and imposition of legends justifying the superiority of the dominant group (953-954), or specific politics of education and language, as demonstrated in the chapter 'The basis of legitimacy':

The scope of determination of social relationships and cultural phenomena by virtue of domination is considerably broader than appears at first sight. For instance, the domination exercised in schools has much to do with the determination of the forms of speech and of written language which are regarded as orthodox. $(1978,215 ; 1980,123)$

This factoring of culture into practices of domination is one of the most noted aspects of Weberian sociology. Bourdieu, for instance, elaborated on the cultural implications of this paradigm of domination-legitimation, which he reconceived as symbolic capital, power or violence, also involving a politics of performativity (1991).

The interconnection between political and cultural-linguistic dimensions was approached differently by Derrida: in The Monolingualism of the Other (1998), he defined an essential 'coloniality' in 'the very language of the Law', in 'law as language' (39). This irreducible coloniality implies the violence of an 'originary "alienation" which institutes every language as a language of the other: the impossible property of a language' (63). I shall return to this structural 'otherness' (or heteronomy) of law in my concluding remarks, as it might suggest another representation of legitimacy, beyond socioontological categories and 'successful' performativities.

Before we get there, Derrida defines the tendency 'to reduce language to the One, that is, to the hegemony of the homogeneous' $(1998,40)$. This attempt at 'homohegemony' is at work in all culture, which implies some epistemic violence or 'domestication', alienation and expropriation, be it in their traditionally 'colonial' form or not. Max Weber's paradigm of legitimation-domination, notably through the guise of educational politics and cultural domestication within the State, strangely resembles a form of 'domestic' coloniality. This recalls the oxymoronic notion of "domestic" intervention', once hypothesised by Cynthia Weber $(1995,106)$; while this notion seems nonsensical according to the protocols of socio-ontology and IR theory, it also provides an alternative model interrogating politics of sovereignty and their reliance on homohegemonic structures. This ipsocratic tendency, which might be translated, in Max Weber's terms, as an effort to monopolise legitimacy, belongs first and foremost to the structure of language itself, thus exceeding in its scope traditional concepts of governmental power, centralised sovereignty or political legitimation. This does not mean that this monopolising effort is not in itself 'legitimate': it is the very legitimacy of performative power at work, characterised, in its forceful effort of self-assertion and self-legitimation, by a tendency to conceal the heterogeneity of the event precisely because heterogeneity signifies the defeat of performativity.

A deconstructive approach to performativity strives to emphasise the fallibility of homohegemonic monopolisations and to do justice to the event before and beyond performative ontologies. The very idea of monopolistic legitimacy supposes the concealment of differential legitimations implied by the logic of interpretability. Derrida, in a critique of Bourdieu, expressed his distrust vis-à-vis the sociological concept of legitimation for 
analogous reasons: all effort of institutionalisation implies a de- and re-contextualisation of legitimacies, that is, a differing legitimation or a differing interpretation of existing legitimacies (which are, in themselves, 'always heterogeneous and worked through by contradictions'). 'This simple fact is enough to threaten the very concept of legitimation to the core: it has no opposite. Nonlegitimacy can appear as such, be its signs ever so discreet, only in a process of prelegitimation' (2002d, 14). The notion that legitimacy is heterogeneous in and through the performed homo-hegemony of the dominant's 'legend' goes to complexify definitions of the State as monopolising legitimate violence. It also implies that there is no 'outside' of legitimacy. Every political situation and domination, even the most centralised in appearance, dissimulates conflicts in legitimacies and interpretations thereof. Incidentally, this very same conviction is what justified Max Weber's suspicion towards what he names the 'juristic' conception of 'sovereignty', which conceals, in the name of sovereign 'unity', the competitive character of transactions and negotiations between different organs within the State $(1978,670)$. The same doubts may be raised with regard to Weber's axiomatics: defining legitimacy as monopolistic operates a performative, forceful stabilisation of differential violences, within the State and beyond, and always in the name of some legendary homo-hegemony.

How does this affect the definition of the State as a strictly 'sociological' object? The expression of (legitimate) sovereignty, through its Weberian translation into the 'monopoly of the legitimate use of physical constraint', is put into question, virtually, with every performative interpretation of its legitimating principles (and of the violence enacted supposedly in the name of these principles). Each interpretative reading of practices, within or outside the State, already constitutes, potentially, a rupture of its monopoly by calling for other legitimations (and by anticipating, at least virtually, the violence of their enforcement). Similarly, each operation of law enforcement attributed to 'the State', even the least violent and most routinised in appearance, potentially betrays the monopoly of legitimate violence because it ultimately depends on interpretative-performative readings, which may always highlight the illegitimate character of such operations. The same can be said about anyone attempting to justify the 'conservation' or 'reproduction' of the so-called 'present' situation, as they must argue their case through invoking some nonpresent past or present, in the name of some ('better' or 'less bad') future. Every time one speaks for 'us', each time one says 'we', 'our present', 'our State', 'our people', they must speak in the name of an unpresentable performative event (Derrida 2002b, 269), and anticipate some other, undefinable 'success' beyond names and legitimacies. The success of this performance can never be fully justified in the presence of the present.

In 'Force of Law', Derrida argued that 'there is something of the [...] revolutionary situation [...] in every reading that founds something new' by providing a transformative, and therefore forceful, interpretation of the law and of its legitimating principles. This reading, because it is already performative, may only appear as illegitimate, unreadable and unintelligible with respect to so-called 'present' norms: its conditions of legitimacy remain 'unreadable in regard to established canons and norms of reading' (Derrida 2002b, 271). Whenever one criticises the present situation, the current 'state' of affairs, one may only do so in the name of different legitimating principles, according to a different enunciation of said principles; however, one must always partly play on something of the previous norm. Anyone calling for a transformation of institutions, be it against the State 
or 'within' the State, must justify her/his efforts by assuming different legitimating principles, differential interpretations of existing legitimacies. This effort of legitimation can only be somewhat violent and illegitimate because it implies delegitimating at least some aspects of the existing order, forecasting different laws (and their enforcement). Due to this constitutive interpretability-fallibility of performativity, what is enforced as legitimate violence may also appear, at least virtually, as illegitimate violence: in "the "logic" of this readable unreadability' (Derrida 2002b, 271), legitimate violence may always be read as violent illegitimacy - both in turn and at once.

Consequently, the notion of 'self-legitimation' becomes nonsensical: legitimation always depends on differential interpretations, which will claim to validate (or invalidate) 'the State' before or beyond the ipseity of a self. There is no 'selfness' of the State. What figures the State in its spectral structure is a series of practices and legitimating conventions, already potentially illegitimate because fundamentally contradictory or incompatible, and phantasmatically gathered through the 'presence' without presence of the State. Beyond performative legitimacy, the State signifies the instantiation (or stabilisation) of this impossible cohabitation (co-haunting) of legitimacy and illegitimacy, legitimacy as illegitimacy, co-implicating the State and its other (the State as its other) in and through what Cynthia Weber may have called an 'impossible' ontology $(1998,92)$. This impossible contradiction is made seemingly possible through the spectral body of a phantasmatic sovereignty, and is re-instituted, each time anew and self-contradictorily, through forceful self-domestication and destructive violences, always physical and symbolic, both locally focused and spectrally disseminated.

Emphasising the phantasmatic dimension of the State's 'domination' is not to say that the phantasm does not have 'undeniable consequences', and often forceful, hurtful implications (Derrida 2011, 185). However, the phantasm escapes, by definition, conditions of performative ontology: self-instantiation, self-presence and sovereign ipseity. If there is 'the State', it involves structural divisibility, suicidal practices and self-betrayals, but also brutal reinventions and violent convulsions which, each time singular, put to question homo-hegemonic sovereignties and their conditions of legitimation: 'the state is both self-protecting and self-destroying, at once remedy and poison'. This constitutes its 'autoimmunitary logic' (Derrida, in Borradori 2003, 124).

We are thus far from defining the State as a homogeneous structure involving the presently, successfully claimed monopoly of legitimate violence. Postulating this 'success' already constitutes a performative, legitimating reading of what the State strives to perform in the form of homo-hegemonic domination. Actually, the term 'domination' (Herrschaft) remains attached to the phantasm of sovereign ipseity of the Lord (Herr, dominus). It is not certain that this concept, as it perpetuates a vision of politics dependent on the ipseity of the self-same, can account for the irreducibly disseminated and differential character of spectral violence.

\section{Phantasmaticity and fictionality}

What remains to be discussed is the 'logic' of the phantasm, beyond traditional limits of psychoanalysis and political theory. According to Derrida, 
psychoanalysis has not yet undertaken and thus still less succeeded in thinking, penetrating, and changing the axioms of the ethical, the juridical, and the political, notably in those seismic places where the theological phantasm of sovereignty quakes and where the most traumatic, [...] the most cruel events of our day are being produced. (2002a, 244)

Exceeding categories of socio-onto-phenomenology, the phantasm involves 'a symptomatology of the unconscious' (57). It implies some vision or visibility, appearance and disappearance of the phenomenal apparition, but escapes the fully visible presence of theoria (contemplation). The phantasm does not present itself: its existence may only be reconstructed, presumed, allegedly testified, and supposes an irreducible appeal to belief and faith, even to 'self-belief' - a notion which signifies a split within the identity of individual ipseity, thus affecting the Weberian motif of 'subjective signification' with irreducible self-division. No one has ever 'seen' a State, its sovereignty or legitimacy. Furthermore, no one can testify absolutely for one's interpretation of the State, and for the promise of ipseity that it supposes. One cannot demonstrate the reality of the phantasm, circumscribe its truth or draw its limits. However, the phantasm cannot be simply rejected as illusion through theoretical dissipation. The phantasmatic is precisely what allows what 'may' be to have some sort of operability: it upholds referentiality without referent. Its non-ontological character does not mean that the phantasm is ineffective; it might even be extremely powerful at other levels, through effects of haunting and 'unconscious beliefs', which suggests an uncanny force of performativity, under the 'amorphous' form of phantasmal eventness (Derrida 2011, 185-186). The phantasm may remain silent, invisible and secret, at once conscious and unconscious. This uncanniness is precisely what makes it most terrifying for ontological conceptualisation. 'Ontology opposes [hauntology] only in a movement of exorcism. Ontology is a conjuration' (Derrida 1994, 202).

However, it would seem that in the State, the phantasmatic should be at its most powerful: 'An omnipotent fantasy, of course, because it is a fantasy of omnipotence. [...] the word sovereignty has only ever translated the performative violence that institutes in law a fiction or a simulacrum' (Derrida 2005b, 106). As a phantasmatically centralised, monopolistic point of referentiality, as the locus of the greatest force and legitimacy, State sovereignty supposedly upholds all phantasmaticity through the attempted legitimation of its own phantasm. This is the very violence of its fabular power. But even so it preserves an irreducible fictionality affecting the conditions and structures of legitimate domination. As a 'subject' (a supposedly sovereign subject), I do as if I could grasp the event of the State as an all-powerful performative; as if it were possible to know once and for all if such a performative is successful or not; and as if I knew what success is. The phantasm signifies the irreducible possibility of fictionality in all language and experience (Derrida 2002c, 354), especially whenever and wherever some sovereign ipseity is concerned. In this spectral economy, the possibility of fiction contaminates all transactions and definitions, all ontologies, which implies that we must speak as if there were no phantasms, as if we knew exactly what we meant when we speak of 'the State', and, first and foremost, as if we knew what we meant when we say ' $I$ ', 'I believe', 'I believe I can say I' (etc.). For instance: 'I believe in the legitimacy of the State', or 'I believe that the State successfully claims the monopoly of legitimate violence'. The 'as if' of the phantasm forces us to abide by an originary fictionality, an irreducible substrate of belief, and this at the very moment when we claim that there may be something other than 
fictions, and that ontological categories may be more than quasi-ontological, phantasmatic categories. There is no other option than to believe that there be more than mere beliefs, more than legitimate beliefs or credible legitimacies: in this nexus of legitimacy and 'religiosity' (Derrida 2002b, 70), the believer's sovereign ipseity and that of the 'thing' believed (par excellence: the theologico-political phantasm of State sovereignty) are mutually fantasised and spectrally cemented. This process of reciprocal haunting makes it impossible to identify the source of legitimation and sovereignty (be it the individual's or the State's): their common origin is this originary belief without opposite, 'this fiduciary "link"' to the other as pure singularity (2002b, 55). Needless to say that, in this appeal, what one calls 'believing' may only appear as paradoxical, fragile and haunted.

\section{Max Weber's 'as if': Macht, domination and legitimacy}

If I insist on the fictionality of the 'as if', that is because it is explicitly and repeatedly mentioned by Max Weber. It constitutes the paradoxical foundation, admittedly 'awkward' $(1978,946)$, of his sociology of domination. According to Weber, the analogical structure of the 'as if' (als ob) remains absolutely 'unavoidable', simply because it allows him to account for domination sociologically, that is, faithfully to 'sociological conceptuality' $(1980,544)$. What is at stake is the possibility of defining domination (Herrschaft) in opposition to the formless concept of Macht. This distinction is crucial, because the 'sociological concept of domination' $(1978,53)$ also determines those of 'politics' and 'the State' (as Herrschaftsstrukturen).

Macht has usually been translated as 'power'. However, it could also be translated as 'force' or 'might', which might be more suitable in this context because the English notion of 'power' often designates legitimate, instituted force (such as State power, which could be rendered in German by the term Gewalt, and that Weber would certainly describe as Herrschaft). Weber clearly specifies that Macht is a very general, potentially pre-political concept, exceeding the scope of a pure sociology of domination: 'The concept of power [Macht] is sociologically amorphous. All conceivable qualities of a person and all conceivable combinations of circumstances may put him [sic] in a position to impose his will in a given situation' $(1978,53)$. Because Macht is not precise enough of a notion, Weber suggests that it be avoided, preferring the more 'technical' concept of domination: 'The sociological concept of domination must hence be more precise and can only mean the probability that a command will be obeyed' $(1978,53)$. Whatever the worth of this conceptual precision, it is of interest that the notion of Macht is from the onset considered as inapplicable in a sociological perspective, which means that political sociology can only concern itself, as sociology of domination, with this representation of domination, understood as the probability that an order will be followed. Weber thus conceives political sociology as a study of the conditions of possibility of compliance or submission, which shall indeed lead to a sociological enactment of the successful reproduction of domination. His theoretical exclusion of the concept of Macht is as much a recognition of epistemic limits (the amorphousness of power or force, unpredictable and escaping ontological formalisation), as it is a delimitation of the field of applicability and domain of competence of sociological methodology. 
There cannot be any socio-ontology of Macht, and this is why one needs a 'precise' conceptualisation of domination.

Legitimacy is the most important, but also the most fragile element of this theoretical architecture. Legitimacy depends on an analogical reasoning which subordinates obedience to an irreducible 'as if'. In a situation of 'domination', everything happens as if the dominated were making the will of the dominant the maxim of their own action:

As 'domination', we shall understand here the following state of affairs: that a manifest will (an 'order') of the 'dominant(s)' intends to affect, and effectively affects, the activity of others (the 'dominated', singular or plural), in such a way that such activity, to a socially relevant degree, occurs as if the dominated had made the content of the dominant's order the very maxim of their activity for its own sake. (This is what we call 'obedience'.)

This formulation, with the 'as if, sounds awkward, but it is unavoidable if one wants to take as basis the concept of domination that we have hypothesised. (M. Weber 1978, 946; 1980, 544; my emphasis)

Why is the 'as if' unavoidable? This is for two correlated and somewhat mutually exclusive reasons. First, it is a requirement of Weber's definition of sociology,

a science concerning itself with the interpretative understanding of social action and thereby with a causal explanation of its course and consequences. We shall speak of 'action' insofar as the acting individual attaches a subjective meaning to his [sic] behaviour - be it overt or covert, omission or acquiescence. $(1978,4)$

In accounting for the 'subjective' signification of obedience, interpretative sociology conceives the 'phenomenon of domination' $(1978,216$; 1980, 124) through the validation of its legitimation. In doing so, it seeks to establish causal inferences, as well as typological and taxonomic classifications of domination-legitimation (more exactly: of different ideal types of dominations in function of their mode of legitimation). Without the assumption ('as if') of this subjective meaning (and thus of general criteria of validation for different types of dominations), there would be no way of dissociating domination from the amorphousness of Macht. Consequently, the conditions of possibility of legitimacy are also the conditions of legitimation of sociological methodology in its capacity to interpret power and domination and, subsequently, politics and the State.

Second, Weber is extremely cautious in determining the conditions of possibility of interpretative sociology - which must presuppose, following empirical cases, a methodological individualism, the recognition of an interplay between honesty and dishonesty, the postulate of self-consciousness, the pondering of irrational motives, and so on (1978, 4-22). The mitigating factors of 'probability', 'plausibility' or 'possibility' (7-20) are thus as much on the side of interpretative methodology as on that of domination itself (understood as the probability that an order will be obeyed). This implies a redoubling of the 'as if': not only the 'dominated' individual seems to act as if the content of the dominant's order determined the maxim of her/his activity for its own sake, but the sociologist-interpreter must proceed as if this 'as if' were sufficient to determine the presence of legitimacy, that is to say to determine the reality, effectiveness and influence of legitimacy as such, as successful - and of the State as such. Because legitimacy 'itself' escapes empiricity, while remaining 'unavoidable' in order to distinguish domination from purely amorphous Macht, the sociologist must proceed as if there were no 'as ifs', and as if interpretability were tantamount to socio-ontological description. This 
conflation supposes the reduction of the interpretative 'as if' (the assumed 'subjective signification' of an activity) into the ontological indication of the presence of legitimate domination as such. This ontological reduction is finally enacted when, despite all 'as ifs', sovereign domination is defined as 'success' - exemplarily through the definition of the State's claim to the monopoly of legitimate violence as essentially 'successful'. This decision suspends all the 'as ifs' so as to validate legitimate domination ontologically, as being-present as such.

\section{Believing beyond ipseity: auto-heteronomic legitimacy}

As a conclusion, I wish to thematise an overarching contradiction in the epistemic principles of Max Weber's interpretative sociology.

On the one hand, Weber strives to account sociologically for so-called 'irrational phenomena': 'sociological investigation attempts to include in its scope various irrational phenomena, such as prophetic, mystic, spiritual and affectual modes of action, formulated in terms of theoretical concepts which are adequate on the level of meaning' $(1978,20 ; 1980,10)$. The consequence of this phenomenology (or phantasmatology) is an inflation of discourses concerned with 'subjective signification', be it rational or irrational. The appeal to 'beliefs in legitimacy' $(1978,31)$ is constant in Economy and Society, and conditions all matters of legitimation, not only in the 'technical', 'sociological' sense of the term, but in its irreducibly disseminal polysemy. The obligatory force of legitimation potentially assumes political, economic or religious dimensions - the three domains being brought together, notably, through the antanaclastic use of the term 'credit' (Kredit) $(1978,588 ; 1980,355)$. The recourse to the credo of 'beliefs', and thus to a certain religiosity, concerns more particularly charismatic legitimacy, which is explicitly defined as secularising a Christian motif: 'The concept of "charisma" ("the gift of grace") is taken from the vocabulary of early Christianity' $(1978,216)$. However, Weber repeatedly emphasises the role of beliefs in relation to specifically 'rational' modes of legitimation, such as State domination (for instance: 1978, 903-904, where notions of 'prestige' and 'consecration' play a significant role). In the last instance, the legitimating power of narrative fiction ('self-legitimation', 'legend') must always find effectiveness through the belief, or 'acceptance' (953), of dominated individuals. Nothing can ultimately prove this acceptance, or, conversely, its 'problematisation' (953). The force of legitimacy remains dependent on the mystique of an 'as if' which, in itself, cannot be empirically observed 'as such', escaping phenomenologisation or ontologisation.

On the other hand, Weber attempts to stabilise the effects of this limitless phantasmaticity by maintaining socio-ontological categories. The main recourse of this ontology is his methodological individualism, anchoring Weber's phantasmatology into an ipsocentric representation of reality. In a fashion reminiscent of Marx and Engels' theory of ideology (such as exposed in The German Ideology), this gesture starts with an anthropological grounding of phantasmata 'in the heads of real men'. 'Collective constructs' are essentially defined as mere 'thoughts' or 'representations', although, as such, they affect 'tremendously' and even 'dominate' the activity of individuals (1978, 14; 1980, 7). Even so, this dominant power of beliefs, which supposedly determines structures of legitimate obedience, remains dependent on the analogical logic of the 'as if'. In many ways, Weber's definition of the domination-obedience structure functions as a parodic 
perversion of Kant's categorical imperative. For instance, from the Groundwork: 'The formal principle of these maxims is, act as if your maxims were to serve at the same time as a universal law (for all rational beings)' (Kant 1997, 45). But while Kant's categorical imperative is the transcendental condition of moral autonomy, Weber formalises, under the structure of legitimate domination, a radical heteronomy, since the dominated individual acts as if s/he were making the content of the dominant's will the maxim of her/his 'own' action. In and through legitimation, domination functions as a transfer of will, as if the dominant's 'will' ventriloquised the dominated, and expressed itself directly through the dominated's action. It happens as if the dominant's 'order' or 'will' did not even need to be enunciated as such, in a sort of machinistic automatism through which legitimate law is enacted without performative interpretation or transformative translation, and without remainder. Of course, Weber makes it perfectly clear that the resources of obedience may be diverse, contradictory and ultimately unknowable. The role of violent coercion, for this matter, is particularly ambiguous. ${ }^{5}$ However, legitimate domination implies 'a minimum will to obey' $(1980,122)$, which supposes some abdication of personal will in the name of some other's law. What Weber fails to conceptualise is the paradoxical, unconscious mechanism of this wilful abdication in favour of another will. In this operation, Weber still sees the ipseic expression of 'subjective meaning', a wilful abandon. The logic of legitimacy and the underlying concept of beliefs ('rational' or not) substantiate the paradox of a 'spontaneous heteronomy', 'voluntary servitude', while maintaining intact the ontological category of ipseity - however phantasmatic and selfcontradictory it might be.

The notion of 'belief' carries the weight of the argument. Everything is laid out by Weber as if it were possible to theorise beliefs, to take 'subjective meaning' as ontological object through and beyond sociological interpretability. This is due to the fact that Weber binds the presence of 'beliefs' to what he believes to be the only scale of signification accessible to sociological interpretation: 'subjective understanding' and methodological individualism $(1978,13)$. Weber justifies this by the notion that sociology should be free of value judgements (Wertfreiheit), so that the sociologist may describe actors' beliefs and thus define (through axiological neutrality) the subjective signification of activity. But what does believing mean, 'this strange and troubling, unheimlich [uncanny] concept of belief or credit, of the act of faith, of trusting'? (Derrida 2014, 153) 'What difference is there between believing and not believing for the unconscious' - and for the phantasm? (Derrida 2011, 157)

'Believing' does not stand for anything simple at all. Derrida (2014) notes that believing does not have an opposite. Believing involves cognitive uncertainty and the phantasmatic 'as if' - that is, a form of representationality foreign to theoretical knowledge, before full presence of consciousness. If I believe in something (for instance, in the legitimacy of the State), it signifies that I only believe in it, and whatever the strength of my faith, believing also implies the seduction of its own simulacrum, self-simulation, selfconvincing and make-believe, and therefore 'nonbelief' (incroyance). I can only let 'myself' believe in something that must also be, in all rigour, somehow unbelievable, quite simply because it cannot be demonstrated beyond the phantasmatic. Spectral possession is already haunted by its opposite. Believing signifies not believing, both at once and in turn: 
To believe is this strange divided state or this strange divided movement, quasi-hypnotic, in which I am not myself, in which I do not know what I know, in which I do not do what I do, in which I doubt the very thing I believe or in which I believe. Believing, in sum, is not believing; to believe is not to believe. And the whole origin of religion, like that of society, culture, the contract in general, has to do with this nonbelief at the heart of believing. (Derrida 2014, 154)

Therefore, Weber's positing of the existence of beliefs as such is already an interpretative gesture, and so are attempts to construct 'believing' as a sociological object. The theoretical positing of beliefs, their description as present and localised signifiers, and their ascription to determinate individuals, already imply a stabilisation of conditions of legitimation, notably through a masking of the essential self-division consubstantial with believing. This self-separation of the believing subject affects all ipseity: 'this internal division, this properly analytic dissociation, this cleavage, this split [schize] of believing haunted by nonbelief is almost quasi-hypnotic, one might say spectral, quasihallucinatory, or unconscious' $(2014,154)$. Such hallucinatory spectacle signifies an irreducible alienation, a dissociative experience in and through which beliefs uncannily escape from the personal control of subjectivity as ipseity: beliefs exceed identity and property, they do not belong. However, Weber's anthropology persists in attaching believing to a logic of ipseity, to an individual 'power-to-be-oneself', notably through the paradoxical possession of one's 'own' beliefs. Even so, the subject's actions are determined heteronomically, as the other's law. The subject is her/himself, but also, and at once, not her/himself.

Through the formulation of the 'as if' consubstantial with his hermeneutics of domination, Weber touches upon something of the paradoxical essence of law and legitimation in relation to ipseity. The paradox is as follows: I have no other choice than, performatively, enacting the law, through my obedience, my beliefs, my interpretations, my practices, and so on, be it in order to 'accept' it or to contest it - but law 'itself' remains fundamentally heterogeneous and inappropriable. This double structure determines our relation to 'Law as Language':

Its experience would be ostensibly autonomous, because I have to speak this law and appropriate it in order to understand it as if I was giving it to myself, but it remains necessarily heteronomous, for such is, at bottom, the essence of any law. (Derrida 1998, 39)

The movement of this inevitable, though ultimately impossible, appropriation is what Derrida names the 'auto-heteronomic' structure of Language as Law. As such, this double structure both allows the peformative position of ipseity and forbids the closure of its performative power into tautological self-legitimation.

This double movement is not without violence. First, it permits the performative positing of law, legitimacy, power, domination, colonialisms, sovereignties, ipseities and all violences which go with these ontological categories. Second, however, it also signifies the essential inappropriability and inappropriateness of such categories, always-already deconstructible, disjointed by the othering violence of the event. This second 'concept' of violence is thus an 'originary alienation', implying a constitutive heterogeneity. It also makes future ameliorations and progress possible: it is an archi-performative promise, whose performance is structurally undecidable and fundamentally pervertible. This 
promise addresses itself to the im-possible other (possible inasmuch as it is impossible), beyond determined conventions, performative self-legitimations and sovereign ipseities.

In his lecture 'Politics as a Vocation', first given in 1919, Max Weber already approached this structural im-possibility of the event, within the State and perhaps beyond, through what I would call the self-excessive character of politics:

It is completely true, and all historical experience confirms it, that what is possible could never have been achieved if one had not constantly reached for the impossible in the world. $(2008,207)$

If we disconnect Weber's political theory from its socio-ontological presuppositions (starting with its methodological individualism and its ipsocratic concept of domination), we have here a definition of the event as fundamentally im-possible and nonlegitimate. The event must exceed conditions of possibility and legitimation attached to traditional performatives. In its im-possibility, the event suspends phantasms of 'successful' sovereignties and legitimacies, performative conventions and beliefs, in order to make law.

As such, the im-possibility of the event is not an accidental characteristic of politics, which would remain localised, for instance, in its revolutionary 'moments' - inseparable, according to Weber, from the 'extra-ordinary' and irrational character of charisma: this 'specifically revolutionary force' $(1978,244)$. On the contrary, the radical a-legitimacy of the event is what makes it possible for politics (and the State) to have a history: 'it is the whole history of law' (Derrida 2002b, 270), a self-differential history. The event signifies the fallibility of historical legitimacies because the conditions of its success and/or failure remain to come.

Why insist on 'fallibility' rather than 'failure'? Simply because, in order to determine an undeniable failure, one that would be absolutely certain and decidable as 'non-success', we would still have to rely on some performative power or transcendental agency, under the form of some sovereign decision based on conditions of legitimacyillegitimacy. By contrast, the fallibility of the performative (fallible in the face of the event) maintains the conditionality of the 'as if' and suggests the coming of the other beyond ontological success or failure. Legitimation-to-come destabilises homohegemonies and their legitimating criteria; it is essentially rebellious to the order of presence and success. It resists performative conventions by materialising an internal excess 'within' the State and already beyond, an 'impower' preceding power and affecting it unconditionally (Derrida 2002a, 98).

The legitimation-to-come signifies the unconditionality of deconstructive interpretability, which disrupts legitimacies by pointing to their structural divisibility and differentiality, forcing them to mutate and to adapt. It is an autoimmune force of transformation, a becoming-other. This force implies an 'unconditional resistance' (Derrida 2002a, 204), first because it is a principle of self-resistance. It resists ipsocentric categories in the name of the other, of another performativity which remains to come, stronger and more legitimate, despite its fallibility, than ontological ipseity. As such, it cannot be ontologised; it cannot give rise to new ontologies. The force of the event does not constitute a 'super- or hyper-sovereignty' (Derrida 2011, 290). Rather, it signifies an infinite process of deposition: a sovereignty in différance. 


\section{Notes}

1. The term 'sovereign' derives from 'superanus', the power above, higher, superior (Derrida 2005a, 168; Bennington 2006).

2. I have modified most translations of Weber's writings. Every time I did, I specified the reference to the existing English translation, followed by the reference to the German text.

3. An analysis of legitimacy in relation to performativity can be found in Lyotard's The Postmodern Condition (1984), which defined performative power as strictly selflegitimating (47). In Excitable Speech (1997), Judith Butler staged a conversation between Bourdieu and Derrida articulating performativity and legitimacy, and highlighting modes of performative resistance to dominant powers.

4. Butler's approach to performativity then diverges from Derrida's, notably by introducing the notion of 'dominant discourse'. Unfortunately, I cannot discuss her argument in the limits of this essay.

5. Max Weber's definition of State authority entertains a perplexing ambiguity concerning the legitimating power of violence itself. In his account of rational-legal domination, State violence is legitimated (that is the 'normal' or normative articulation between violence and legitimacy), but it is also said to be legitimating: centralised political violence (and especially the power 'over life and death') 'guarantees' legitimacy, and provides a surplus of 'prestige', even 'consecration' to the modern institution of State sovereignty $(1978,904)$. This articulation between violence and legitimation is precarious and somewhat self-contradictory: on the one hand, legitimate domination implies that obedience must be spontaneous, and cannot exclusively result from violence, threat, intimidation or fear (37) (because, in this case, domination would conflate with 'amorphous' forms of Macht as coercion, whatever its resources); on the other hand, political domination (for instance, the State's) is explicitly defined as the type of domination whose 'specific' characteristic is the use of 'physical force (Gewaltsamkeit)', or the threat of its use, as the 'last resort' of its domination (54). Between the actual exercise of violence, the threat of using force (inducing fear or intimidation), and 'spontaneous', legitimate obedience per se (which supposedly excludes violence and threat), it becomes difficult to delineate legitimacy and nonlegitimacy, Herrschaft or Macht, and to decide if obedience is actually based on fear or on legitimacy-beliefs. On these premises, how does one define and circumscribe 'fear' as opposed to 'beliefs'? And how could this difficulty not contaminate conceptualisations of legitimate domination as consensual?

\section{Funding}

Open access for this article was funded by King's College London.

\section{References}

Ashley, R. K. 1988. "Untying the Sovereign State: A Double Reading of the Anarchy Problematique." Millennium - Journal of International Studies 17 (2): 227-262. doi:10.1177/ 03058298880170020901.

Austin, J. L. 1962. How to Do Things with Words. The William James Lectures Delivered at Harvard University in 1955. London: Oxford University Press.

Bennington, G. 2006. "The Fall of Sovereignty." Epoché 10 (2): 395-406. doi:10.5840/ epoche20061027.

Borradori, G. 2003. Philosophy in a Time of terror. Dialogues with Jürgen Habermas and Jacques Derrida. Chicago: The University of Chicago Press.

Bourdieu, P. 1991. Language and Symbolic Power. Cambridge: Polity Press. 
Butler, J. 1997. Excitable Speech. A Politics of the Performative. New York: Routledge.

Campbell, D. 1998. National Deconstruction. Violence, Identity, and Justice in Bosnia. Minneapolis \& London: University of Minnesota Press.

Derrida, J. 1994. Specters of Marx. Translated by Peggy Kamuf. New York: Routledge.

Derrida, J. 1997. Of Grammatology. Corrected edition, Translated by Gayatri Chakravorty Spivak. Baltimore: Johns Hopkins University Press.

Derrida, J. 1998. Monolingualism of the Other; or, The Prosthesis of Origin. Translated by Patrick Mensah. Stanford: Stanford University Press.

Derrida, J. 2002a. Without Alibi. Translated and edited by Peggy Kamuf. Stanford: Stanford University Press.

Derrida, J. 2002b. Acts of Religion. Edited by Gil Anidjar. London: Routledge.

Derrida, J. 2002c. Negotiations. Translated and edited by Elizabeth Rottenberg. Stanford: Stanford University Press.

Derrida, J. 2002d. Who's Afraid of Philosophy? Right to Philosophy 1. Translated by Jan Plug. Stanford: Stanford University Press.

Derrida, J. 2005a. Rogues. Two Essays on Reason. Translated by Pascale-Anne Brault, and Michael Naas. Stanford: Stanford University Press.

Derrida, J. 2005b. Paper Machine. Translated by Rachel Bowlby. Stanford: Stanford University Press.

Derrida, J. 2011. The Beast and the Sovereign Vol. II. Translated by Geoffrey Bennington. Chicago: The University of Chicago Press.

Derrida, J. 2014. The Death Penalty Vol. I. Translated by Peggy Kamuf. Chicago: The University of Chicago Press.

Kant, I. 1997. Groundwork of the Metaphysics of Morals. Translated and edited by Mary Gregor. Cambridge: Cambridge University press.

Lyotard, J.-F. 1984. The Postmodern Condition: A Report on Knowledge. Translated by Geoff Bennington, and Brian Massumi. Manchester: Manchester University Press.

Thomson, J. 1994. Mercenaries, Pirates, and Sovereigns. State-building and Extraterritorial Violence in Early Modern Europe. Princeton: Princeton University Press.

Walker, R. B. J. 1993a. "Violence, Modernity, Silence: From Max Weber to International Relations." In The Political Subject of Violence, edited by D. Campbell, and M. Dillon, 137-160. Manchester: Manchester University Press.

Walker, R. B. J. 1993b. Inside/Outside: International Relations as Political Theory. Cambridge: Cambridge University Press.

Walker, R. B. J. 2010. After the Globe, Before the World. New York: Routledge.

Weber, C. 1995. Simulating Sovereignty. Cambridge: Cambridge University press.

Weber, C. 1998. "Performative States." Millennium - Journal of International Studies 27 (1): 77-95. doi:10.1177/03058298980270011101.

Weber, C. 2010. International Relations Theory. A Critical Introduction. 3rd ed. London: Routledge.

Weber, C., and T. J. Biersteker, eds. 1996. State Sovereignty as Social Construct. Cambridge: Cambridge University Press.

Weber, M. 1978. Economy and Society. An Outline of Interpretive Sociology. London: University of California Press.

Weber, M. 1980. Wirtschaft und Gesellschaft. Grundriss der Verstehenden Soziologie. Tübingen: J.C.B. Mohr (Paul Siebeck).

Weber, M. 2008. Complete Writings on Academic and Political Vocations. Edited by J. Dreijmanis, Translated by G. C. Wells. New York: Algora Publishing.

Weber, M. 2012. Gesammelte Politische Schriften. Paderhorn: Salzwasser-Verlag. 